\title{
Biosynthesis of Astaxanthin as a Main Carotenoid in the Heterobasidiomycetous Yeast Xanthophyllomyces dendrorhous
}

\author{
Jose L. Barredo ${ }^{1}$, Carlos García-Estrada ${ }^{2,3}$, Katarina Kosalkova ${ }^{2}$ and Carlos Barreiro ${ }^{2,4, *}$ \\ 1 CRYSTAL PHARMA S.A.U. Parque Tecnológico de León, C/Nicostrato Vela s/n, 24009 León, Spain; \\ JoseLuis.Barredo@amriglobal.com \\ 2 INBIOTEC (Instituto de Biotecnología de León), Avda. Real, 1, 24006 León, Spain; \\ cgare@unileon.es (C.G.-E.); kkos@unileon.es (K.K.) \\ 3 Área de Toxicología, Departamento de Ciencias Biomédicas, Universidad de León, Campus de Vegazana, \\ 24071 León, Spain \\ 4 Área de Microbiología, Departamento de Biología Molecular, Universidad de León, Campus de Ponferrada, \\ Avda, Astorga, s/n, 24400 Ponferrada, Spain \\ * Correspondence: c.barreiro@unileon.es; Tel.: +34-987-210-308; Fax: +34-987-210-388
}

Received: 13 June 2017; Accepted: 27 July 2017; Published: 30 July 2017

\begin{abstract}
Carotenoids are organic lipophilic yellow to orange and reddish pigments of terpenoid nature that are usually composed of eight isoprene units. This group of secondary metabolites includes carotenes and xanthophylls, which can be naturally obtained from photosynthetic organisms, some fungi, and bacteria. One of the microorganisms able to synthesise carotenoids is the heterobasidiomycetous yeast Xanthophyllomyces dendrorhous, which represents the teleomorphic state of Phaffia rhodozyma, and is mainly used for the production of the xanthophyll astaxanthin. Upgraded knowledge on the biosynthetic pathway of the main carotenoids synthesised by X. dendrorhous, the biotechnology-based improvement of astaxanthin production, as well as the current omics approaches available in this yeast are reviewed in depth.
\end{abstract}

Keywords: Xanthophyllomyces dendrorhous; Phaffia rhodozyma; astaxanthin; carotenoids; carotenes; xanthophylls

\section{Introduction: Xanthophyllomyces dendrorhous and Carotenoids}

The carotenoids group includes tetraterpenoid organic pigments, the majority comprising of eight isoprene units with a C40 skeleton. These lipophilic metabolites are insoluble in water and contain a long polyene central chain of conjugated double bonds that functions as a chromophore (400-500 nanometers being the electromagnetic spectrum where carotenoids absorb maximally) responsible for the characteristic yellow to orange and reddish colours of these compounds [1].

All naturally occurring carotenoids are produced by photosynthetic species (including plants and algae), and by some classes of fungi and non-photosynthetic bacteria [2-5]. In general, animals are unable to produce their own carotenoids and therefore, the only way to obtain these compounds is from their diet.

Carotenoids can be classified according to the oxygenation degree into carotenes and xanthophylls. Carotenes (e.g., $\beta$-carotene, $\alpha$-carotene or lycopene) are strictly hydrocarbons (non-oxygenated molecules), whereas xanthophylls (e.g., lutein, zeaxanthin, canthaxanthin, or astaxanthin) are oxygenated molecules (oxycarotenoids) with a hydroxy, epoxy, and/or oxo group [6]. These compounds play different roles. Thus, in photosynthesizing species they are associated with the light harvesting complexes acting as accessory light-harvesting pigments, effectively extending the 
range of light absorbed by the photosynthetic apparatus. In those organisms, carotenoids also play a photoprotective role by quenching triplet state chlorophyll molecules and scavenging singlet oxygen and other toxic oxygen species formed within the chloroplast, and in the case of zeaxanthin, by dissipating harmful excess excitation energy under stress conditions $[7,8]$. Besides, carotenoids provide organisms of bright yellow, red, or orange and their main function in all non-photosynthetic organisms seems to be (photo) protection. They are known to be very efficient physical and chemical quenchers of singlet oxygen $\left({ }^{1} \mathrm{O}_{2}\right)$, as well as potent scavengers of other reactive oxygen species, playing an important role as antioxidants $[9,10]$. Carotenoids are also important precursors of retinol (vitamin A precursors) [11].

More than 700 types of carotenoids have been found from natural sources so far [5,12]. The carotenoids market in $2019 / 2020$ is supposed to reach $\$ 1.5-1.8$ billion with a compound annual growth rate of $3.9 \%[13,14]$ and due to the extensive commercial and industrial uses of carotenoids (mainly lutein and astaxanthin), the demand of these compounds is high around the world. Therefore, several biological platforms are used for the biotechnological production of natural carotenoids for their use in food and feed, cosmetics, and the chemical and pharmaceutical industries [15].

One of these platforms is the red/pink-pigmented heterobasidiomycetous yeast Xanthophyllomyces dendrorhous (the teleomorphic state of Phaffia rhodozyma), which was isolated in the late 1960s from tree-exudates in Japan and Alaska [16] and naturally produces and accumulates the xanthophyll astaxanthin [17]. This yeast can be considered as a cell-factory for the production of industrially valuable carotenoids [18], since the genome of X. dendrorhous CBS6938 has been sequenced [19] and biotechnology tools for the genetic manipulations of this microorganism are available [20-23]. In addition, this yeast does not require light for accumulation of astaxanthin, is able to metabolise many kinds of saccharides under both aerobic and anaerobic conditions, and reproduces at relatively high growth rates [24]. Besides, its approval as a colour stabiliser for fish feed supplementation by FDA (U.S. Food and Drug Administration) supports the natural production as an interesting methodology (https:/ / www.accessdata.fda.gov/scripts/cdrh/cfdocs/cfcfr/CFRSearch.cfm?fr=73.355).

In addition to astaxanthin, $X$. dendrorhous is able to produce several carotenoids, including $\beta$-carotene, canthaxanthin, zeaxanthin, and astaxanthin via mevalonate pathway (Figure 1). $\beta$-carotene, a red-orange carotenoid, possesses $\beta$-rings at both ends and serves as an intermediary molecule for the biosynthesis of astaxanthin $[25,26]$. This compound is widely used in the food, feed, cosmetic, and pharmaceutical industries due to its potent colouring traits, antioxidant properties, and provitamin A activity, since it appears to be the most important vitamin A precursor for vertebrate animal species [27]. Besides, $\beta$-carotene adds colour to beverages, dairy products, confectionery, and many other commodities, and together with astaxanthin, they are the most important carotenoids from a commercial point of view. The orange-red pigment canthaxanthin ( $\beta, \beta$-carotene- $4,4^{\prime}$-dione) is a xanthophyll with antioxidant properties widely used in aquaculture and poultry farming, providing the characteristic colour to fish flesh, chicken skin, and egg yolk [28,29]. Zeaxanthin ( $\beta, \beta$-carotene-3,3'-diol) is a yellow xanthophyll alcohol important for vision, since together with lutein and meso-zeaxanthin, they are present in high concentrations within the oval-shaped macular pigmented area near the centre of the retina of the eye [30,31], thus playing an important protective role against several eye diseases [32]. Astaxanthin ( $3,3^{\prime}$-dihydroxy- $\beta, \beta$-carotene- $4,4^{\prime}$-dione) is a red-orange pigment with a market value ranging from $\$ 2500-7000 / \mathrm{kg}$ whose global market was valued at US\$447 in 2014 and expected to reach a value of US $\$ 1.1$ billion by 2020 [14,33]. After $\beta$-carotene, astaxanthin is the second most important carotenoid, representing about $29 \%$ of total carotenoid sales [34]. This pigment has strong antioxidant properties and is used as a feed additive in salmon and trout aquacultures as well as in chicken and quail farming and egg production $[6,35,36]$. Other properties have been described for astaxanthin, such as beneficial effects in cardiovascular, immune, inflammatory, diabetes, carcinogenic, and neurodegenerative diseases, and as an antiaging and sun proofing agent [15,37-41]. The commercial origin of astaxanthin is from either chemical synthesis or natural resources such as 
fermentative production (microalgae, yeast) and crustacean byproducts [36,41]. Therefore, more than $95 \%$ of the global market refers to synthetically obtained astaxanthin, which presents lower production costs (around $\$ 1000 / \mathrm{kg}$ ) than the biological alternative. Nowadays, the major manufacturers are DSM (The Netherlands), BASF (France), and NHU (China). However, its petrochemical origin limits the final use, which is boosting the natural sources of this carotenoid [14,41]. Thus, astaxanthin from natural sources, including bacteria such as Paracoccus carotinifaciens, yeasts like X. dendrorhous, or algae like Haematococcus pluvialis, is a realistic alternative to synthetic astaxanthin.

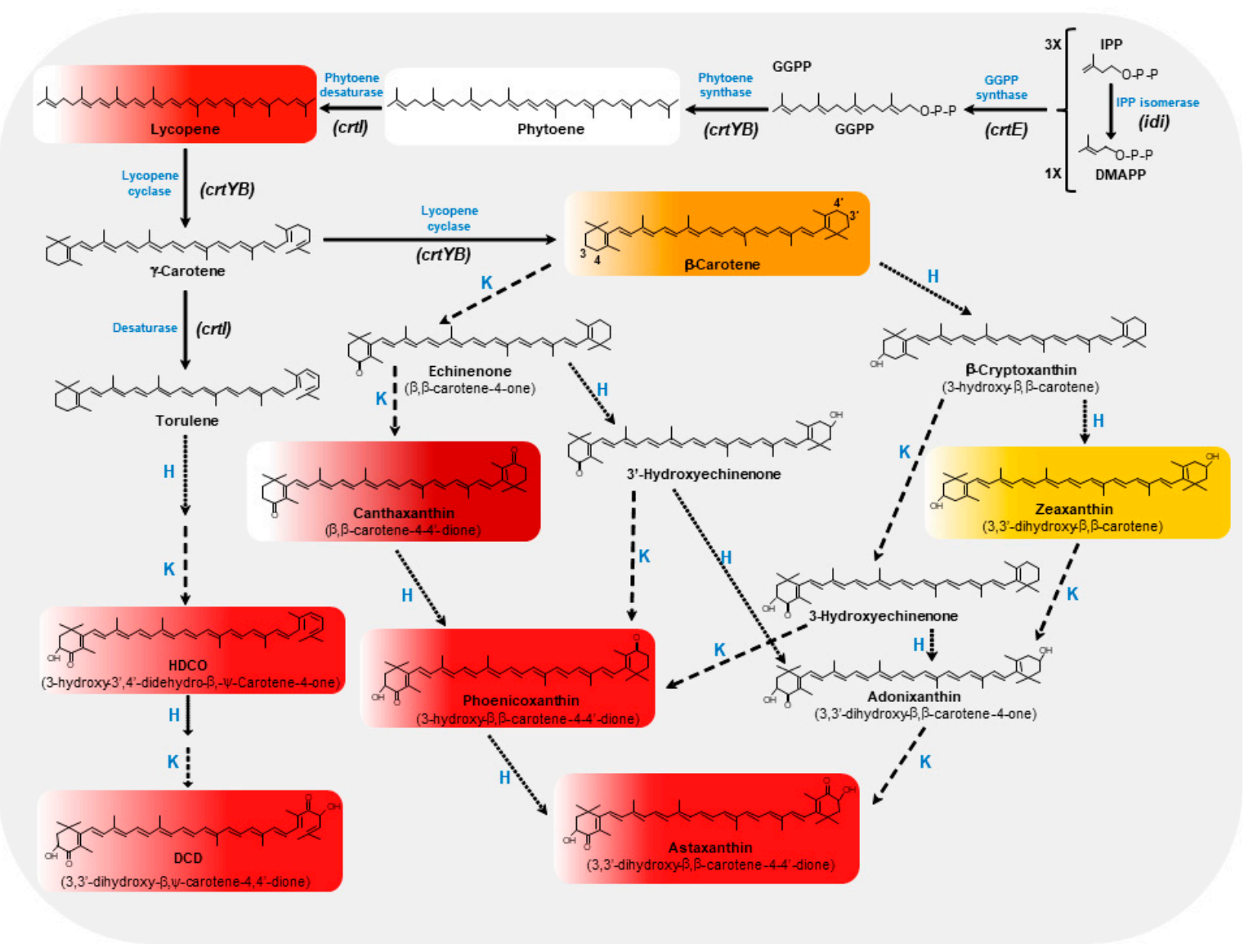

Figure 1. Astaxanthin biosynthetic pathway in X. dendrorhous. Initially, a molecule of dimethylallyl pyrophosphate (DMAPP) and three molecules of isopentenyl pyrophosphate (IPP) are combined to obtain geranylgeranyl pyrophosphate (GGPP) by means of the GGPP synthase. Secondly, two molecules of GGPP are coupled by the phytoene synthase ( $\operatorname{crt} Y B$ gene) to reach phytoene. The phytoene desaturase(crtI gene) introduces four double bonds in the molecule of phytoene to to obtain lycopene. Then, the lycopene cyclase ( $\operatorname{cr} Y B$ gene) converts one of the $\psi$ acyclic ends of lycopene as $\beta$-ring to form $\gamma$-carotene, and subsequently the other to form $\beta$-carotene. Xanthophylls bioconversion in $X$. dendrorhous from $\beta$-carotene and $\gamma$-carotene includes the addition of two 4-keto groups in the molecule of $\beta$-carotene by the ketolase $(K$, discontinuous line) activity, and the inclusion of two 3-hydroxy groups by the hydroxylase $(\mathrm{H}$, continuous dotted line) activity. Both $\mathrm{K}$ and $\mathrm{H}$ activities are presented in a single enzyme (astaxanthin synthetase; $\mathrm{CrtS}$ ) encoded by a single gene (crtS). The cytochrome $\mathrm{P} 450$ reductase encoded by the $c r t R$ gene is a $\mathrm{CrtS}$ helper protein, providing with electrons for substrate oxygenation. The existence of a monocyclic pathway to DCD was also proposed [42]. Main carotenoids detected in X. dendrorhous broths are shown inside a rectangle in concordance with their natural colours. This figure has been based on Rodríguez-Sáiz and co-workers [43]. 
The aim of this review is to provide an up-to-date version of the the carotenoids biosynthetic pathway of $X$. dendrorhous, together with the main biotechnology approaches and omics tools that have been applied to this yeast for the improvement of astaxanthin production.

\section{The Biosynthetic Pathway of Astaxanthin in X. dendrorhous}

The astaxanthin biosynthetic pathway is encoded by six genes (crtI, crtL, crtR, crtO, crtW, and $c r t Z$ ), which present an evolutionary pattern (eukaryotic and prokaryotic) characterised by lateral gene transfer and gene duplication events. These genes are more conserved in plants and algae than in any other bacterial phyla, where the structural genes evolve slower than the regulatory genes [44]. This biosynthetic pathway (Figure 1) has been widely studied in X. dendrorhous [45-48]. Thus, the biosynthesis begins with a $\mathrm{C} 5$ isoprene unit to which prenyl transferases sequentially add three other isoprenic units [49], resulting in the formation of C20 geranylgeranyl-pyrophosphate (GGPP). The active forms of the isoprene unit are isopentenyl-pyrophosphate (IPP) and its allylic isomer dimethylallyl-pyrophosphate (DMAPP). In most eukaryotes, IPP derives from the mevalonate pathway [50], while in prokaryotes and in plant plastids, it is synthesised via the 2-C-methyl-D-erythritol-4-phosphate (MEP) pathway, which is also known as the non-mevalonate pathway [51].

The idi gene encodes IPP isomerase, which catalyses the isomerisation of IPP to DMAPP [52], and then both molecules are joined together, generating C10-geranyl pyrophosphate (GPP), the precursor of monoterpenes [53]. The addition of a second molecule of IPP to GPP by prenyl transferases gives the C15 precursor of sesquiterpenes, farnesyl pyrophosphate (FPP), which is converted into GGPP [54] by the further addition of IPP by the GGPP synthase (encoded by the $c r t E$ gene). Next, phytoene synthase (encoded by the crtYB gene) links two molecules of GGPP in a tail-to-tail manner, yielding phytoene [50,55]. This is the first carotenoid synthesised in the pathway, which is colourless as it has a symmetrical carotenoid skeleton with only three conjugated double bonds. The structural diversity of carotenoids is generated by further modifications, including desaturations, cyclisations, isomerisations, and oxygenations [56]. The phytoene synthase of fungi is a bifunctional enzyme that has both phytoene synthase and lycopene cyclase activities, which gives rise to $\beta$-carotene. In this particular enzyme, encoded by the $c r t Y B$ gene, the phytoene synthase and lycopene cyclase activities are located in the $\mathrm{C}$-terminal and $\mathrm{N}$-terminal functional domains, respectively.

Next, phytoene is desaturated by phytoene desaturase (encoded by the crtI gene) [3,57] by the incorporation of two, three, four, or five double bonds, thus producing the coloured carotenoids: (i) $\zeta$-carotene (yellow, synthesised by some plants, cyanobacteria, and algae); (ii) neurosporene (yellow, accumulates in Rhodobacter capsulatus and R. sphaeroides); (iii) lycopene (red, found in most eubacteria and fungi) or (iv) 3,4-didehydrolycopene (found in the mold Neurospora crassa) [50], respectively.

Although there are acyclic carotenoids, the cyclisation of lycopene is a frequent step in the biosynthesis of carotenoids, forming three types of ionone rings: $\beta_{--}^{-,} \varepsilon^{-}$, and $\gamma$ (gamma)-rings (Britton 1998). The $\beta$-ring is the most common, the $\varepsilon$-ring is found in plants and in some algae, and the $\gamma$-ring is the rarest one. The lycopene cyclase (also encoded by the $\operatorname{crt} Y B$ gene) [58] sequentially converts the $\psi$ acyclic ends of lycopene to $\beta$ rings to form $\gamma$-carotene and $\beta$-carotene [55].

The synthesis of xanthophylls involves the oxidation of post-phytoene carotenoid molecules, mainly from $\alpha$ - and $\beta$-carotenes, resulting in oxygenated products with hydroxyl-, epoxy-, and oxo-functional groups. The formation of astaxanthin from $\beta$-carotene involves the introduction of a hydroxyl and a keto group at $C 3$ and $C 4$, respectively, for each of the $\beta$-ionone rings. Two enzymatic activities convert $\beta$-carotene into astaxanthin through several biosynthetic intermediates: a ketolase, which incorporates two 4-keto groups in the molecule of $\beta$-carotene, and a hydroxylase, which introduces two 3-hydroxy groups. In X. dendrorhous, both activities are included in a single enzyme (astaxanthin synthetase; CrtS), belonging to the cytochrome P450 family and encoded by the crtS gene, which sequentially catalyses 4 -ketolation of $\beta$-carotene followed by 3 -hydroxylation $[25,26]$. In contrast, two independent genes have been described in other astaxanthin producing microorganisms. 
A cytochrome P450 reductase, encoded by the $c r t R$ gene, has been shown to have an auxiliary role to $\mathrm{CrtS}$ in $\mathrm{X}$. dendrorhous, providing the necessary electrons for substrate oxygenation [59]. A mutant of $X$. dendrorhous lacking the $c r t R$ gene accumulates $\beta$-carotene and is unable to synthesise astaxanthin, demonstrating that $\mathrm{CrtR}$ is essential for the synthesis of astaxanthin [59]. In Saccharomyces cerevisiae strains expressing $X$. dendrorhous carotenogenic genes, astaxanthin production was only achieved when CrtS was co-expressed with CrtR [60].

The existence of a monocyclic pathway diverging from the dicyclic pathway at neurosporene and proceeding through $\beta$-zeacarotene, 3,4-didehydrolycopene, torulene, 3-hydroxy-3' $4^{\prime}$-didehydro- $\beta$, $\psi$-carotene-4-one (HDCO) to the end product $3,3^{\prime}$-dihydroxy- $\beta, \psi$-carotene- $4,4^{\prime}$-dione (DCD) (Figure 1 ) was also proposed [42].

\section{Biotechnology-Based Improvement of Astaxanthin Production in X. dendrorhous}

Chemical synthesis is relatively complex even for simple carotenoids such as $\beta$-carotene. Thus, several companies and academic laboratories have investigated biological sources of astaxanthin. Among these sources, P. rhodozyma/X. dendrorhous and the microalga H. pluvialis stand out because of their ability to synthesise astaxanthin. However, biological production of astaxanthin in natural isolates presents a well-known drawback; the very low specific production. Thus, the specific astaxanthin production of wild type strains of $X$. dendrorhous is $200-400 \mu \mathrm{g} / \mathrm{g}$ of yeast dry weight [61,62]. Besides, the thickness of yeast cell walls and capsule, which apparently hinders astaxanthin uptake, seems to be also relevant for production and downstream processing. In order to obtain a competitive natural source of this xanthophyll it has been necessary to increase this production by a factor of 10-50. Classical random mutagenesis methods by using physical or chemicals agents have been successfully applied [34,43,63-65]. Some of these mutants obtained by random mutagenesis and screening with relevant dry cell weight productivity rates [P. rhodozyma E5042 $(2.5 \mathrm{mg} / \mathrm{g})$; X. dendrorhous VKPM Y2476 (4.1 mg/g); P. rhodozyma JMU-MVP114 (6.01 mg/g)] [66-68]. Nevertheless, one of the drawbacks of this approach is the introduction of secondary mutations that may affect the physiology, viability, or metabolic capacity of the cell. Besides, genetic instability of the mutants, reduction in the production of biomass, and accumulation of undesired intermediaries have frequently been detected $[64,69]$. The selection of astaxanthin super-producer mutants in solid medium conditioned the detection of strains due to the low levels of aeration, which inhibit the production of oxygenated carotenoids. As a result, different selection procedures have been developed. On the one hand, positive selection by means of inhibitors of carotenogenesis ( $\beta$-ionone, diphenylamine) has been developed [70]. On the other hand, negative selection, such as the increased sensitivity of carotenoid-producing strains to antimycin A (a respiratory inhibitor), has been another option [71,72].

The yield improvement of microbial products has been traditionally faced up by means of: (i) treatment with mutagenic agents (e.g., nitrogen mustards, ultraviolet irradiation, X-ray); (ii) increasing the biosynthetic genes; or (iii) redirecting the metabolic precursors [73]. As a consequence, a promising strategy is metabolic engineering (see Table 1), which includes: (i) the overexpression of carotenoid biosynthetic genes (e.g., crtYB gene); (ii) the metabolic flow increase towards the synthesis of specific pathway precursor molecules (e.g., geranylgeranyl-pyrophosphate synthase encoding gene $(c r t E))$, or (iii) the supplementation with carotenogenesis precursors (e.g., mevalonate) $[20,47,62,74,75]$. However, this metabolic redirection, which can be included in the new trends of synthetic biology, has needed several methodological updates prior to validating the final effects along the astaxanthin production improvement history. As an example, transformation methods for Xanthophyllomyces have been developed and optimised using (i) constitutive promoters from the yeast itself [e.g., actin, glyceraldehyde-3-phosphate dehydrogenase $(g p d)$ or NADP-dependent glutamate dehydrogenase $(g d h A)$ genes]; (ii) stable integration in the genome by means of the ribosomal DNA of X. dendrorhous introduced into the transformation vectors; and (iii) optimised resistance genes (e.g., kanamycin resistance gene of transposon Tn5 or hygromycin resistance gene $(h p h))$ [21,76]. Under optimum 
conditions, the transformation efficiency obtained was $1 \times 10^{3}$ transformants per microgram of plasmid DNA [76].

Table 1. Examples summary of X. dendrorhous (P. rhodozyma) genetic engineering.

\begin{tabular}{|c|c|c|c|}
\hline Targets & Approach & Result & Ref. \\
\hline $\operatorname{crtYB}$ gene & Deactivation & No carotenoids & [48] \\
\hline $\operatorname{crt} Y B$ gene & Overexpression & $\begin{array}{l}\text { Accumulation of } \beta \text {-carotene and } \\
\text { echinenone }\end{array}$ & [48] \\
\hline crtI gene & Overexpression & $\begin{array}{l}\text { Increase torulene and HDCO and } \\
\text { decrease echinenone, L-carotene } \\
\text { and astaxanthin }\end{array}$ & [48] \\
\hline crtR gene & Description of its role & $\begin{array}{l}\text { Required together with the crtS } \\
\text { gene for the conversion of } \\
\beta \text {-carotene to astaxanthin. }\end{array}$ & [59] \\
\hline double cyp61 genes & Deletion & $\begin{array}{c}\text { Enhanced astaxanthin production } \\
\text { by } 1,4 \text {-fold compared with the } \\
\text { parental strain }\end{array}$ & [77] \\
\hline crtE gene under Padh4r & Evaluation of promotors & $\begin{array}{c}\text { Increase in intracellular } \\
\text { astaxanthin by } 1.7 \text {-fold compared } \\
\text { with parental }\end{array}$ & [78] \\
\hline$a c a T, h m g S$ and $h m g R$ genes & Triple overexpression & $\begin{array}{l}\text { Enhanced volumetric astaxanthin } \\
\text { production by } 1.4 \text {-fold compared } \\
\text { with that of the control strain }\end{array}$ & [23] \\
\hline $\begin{array}{c}\text { acaT/hmgS/hmgR/crtE/crtS } \\
\text { genes }\end{array}$ & $\begin{array}{c}\text { Combined } \\
\text { overexpression }\end{array}$ & $\begin{array}{l}\text { Enhanced volumetric astaxanthin } \\
\text { production by } 2.1 \text {-fold higher } \\
\text { compared with the control strain }\end{array}$ & [23] \\
\hline $\begin{array}{l}\text { Combination of } \\
\text { conventional mutagenesis } \\
\text { and } \operatorname{crt} Y B \text { gene expression }\end{array}$ & $\begin{array}{l}\text { Combined } \\
\text { overexpression }\end{array}$ & $\begin{array}{l}22 \text { times higher astaxanthin } \\
\text { specific production than for the } \\
\text { wild type }\end{array}$ & [75] \\
\hline
\end{tabular}

The carotenoid pathway of X. dendrorhous is well established (Figure 1). This fact has enabled the cloning process of all genes involved in phytoene synthesis, phytoene desaturation, and cyclisation and formation of 3-hydroxy and 4-keto. Thus, knowledge of the molecular biology of X. dendrorhous allows researchers to direct the genetic modifications and increase the metabolic precursors flow to the carotenoid biosynthetic pathway $[48,59,79,80]$. In order to divert metabolite flow from the sterol pathway towards carotenoid biosynthesis, X. dendrorhous was transformed with the $c r t E$ cDNA (geranylgeranyl pyrophosphate synthase). Transformants were obtained with higher carotenoid levels including astaxanthin due to increased levels of geranylgeranyl pyrophosphate synthase [74].

The genetic improvement of Xanthophyllomyces strains by metabolic engineering has been achieved by upregulating phytoene synthase and lycopene cyclase leading to an increase in $\beta$-carotene and echinenone titres. These results suggested that the oxygenation reactions might be rate limiting [48]. The combination of chemical mutagenesis and genetic engineering by targeting limiting reactions (including overexpression of $c r t Y B$ and $c r t S$ genes) led to the generation of an overproducing strain of astaxanthin (9.7 mg per gram of dry weight) [75]. These authors described the construction of new transformation plasmids for the stepwise expression of the bottleneck genes in the carotenoid biosynthetic pathway. As a result, titres were comparable to those provided by H. pluvialis, the leading commercial producer of natural astaxanthin [22].

Enhancement of $c r t S$ gene transcriptional levels led to an increase in the transcription levels of related genes $(c r t E, \operatorname{crt} Y B, c r t I)$ in the astaxanthin biosynthetic pathway. A scheme of carotenoid biosynthesis in $X$. dendrorhous involving alternative bicyclic and monocyclic pathways was proposed by Chi and co-workers in 2015 [81]. 
The limiting step in the carotenoid pathway is phytoene synthase. In order to increase the $\operatorname{cr}$ tYB gene copy number, integration plasmids were constructed. Thus, the transformants with higher copy number accumulated carotenoid intermediates missed in the parental strain. Some of them are substrates and intermediates of astaxanthin synthase, which can be transformed to astaxanthin by the addition of the astaxanthin synthase gene [82].

Recently, a system to completely delete target diploid genes in X. dendrorhous was developed. Diploid CYP61 genes involved in the synthesis of ergosterol that inhibits the pathway for mevalonate (substrate for isoprenoid biosynthesis), were deleted. Ergosterol biosynthesis was decreased, whereas astaxanthin production was approximately 1.4-fold higher than the parental strain [77].

Many reports have been published about astaxanthin fermentation in X. dendrorhous, but there are few reports about large-scale production. In order to produce astaxanthin by biotechnological processes, the scale-up step from lab scale to industry scale is essential. Zheng and co-workers in 2006 [83] reported data from fermentation at $10 \mathrm{~m}^{3}$ scale, where the cellular astaxanthin titres reached $2.57 \mathrm{mg} / \mathrm{g}$ dry cell.

Light is capital in astaxanthin biosynthesis. Light exposure stimulates total production of carotenoids (mainly astaxanthin) in Xanthophyllomyces and has a negative effect on growth [72]. Therefore, the effect of white and ultraviolet light has been tested. Astaxanthin production by fermentation of X. dendrorhous was significantly improved at the flask scale by white light $(4.0 \mathrm{mg} / \mathrm{g})$ and by ultraviolet light $(4.4 \mathrm{mg} / \mathrm{g})$. A semi-industrial process at the $800-\mathrm{L}$ scale for astaxanthin production by fermentation of $X$. dendrorhous was significantly improved by white light and glucose feeding $(4.1 \mathrm{mg} / \mathrm{g})$ [84].

\section{Omics of $X$. dendrorhous: Genomics, Transcriptomics, Proteomics, and Metabolomics}

As was indicated above, the metabolic redirection is a suitable reality. It can be enhanced when it is supported by omics technologies, which have been tackled in this yeast from three points of view: genomics, transcriptomics, and proteomics.

The first genomic analysis was done by using pulsed field gel electrophoresis, which defined a putative genome size of $25 \mathrm{Mb}$ [85]. This genome size has been recently redefined by means of the Illumina sequencing methodology (see Table 2 for extraction protocols) [19,86]. As a result, $X$. dendrorhous presents a $19.50 \mathrm{Mb}$ genome with 6385 protein-coding genes [19]. These data were slightly lower (ca. $19 \mathrm{Mb}$ and $6000 \mathrm{ORFs}$ ) when two different strains (CBS 7918 ${ }^{\mathrm{T}}$, CRUB 1149), in addition to the previously sequenced one (CBS 6938), were analysed. Thus, based on these three strains, which can be considered as different varieties in future, the existence of genetic heterogeneity within this red-pigmented yeast was demonstrated [87]. Genome-based pathway analysis presented sterols and carotenoids biosynthesis as the two prominent terpenoid pathways in X. dendrorhous. These genes do not follow the typical cluster arrangement for other specific biosynthesis pathways of fungi, which is a peculiarity of this yeast. Besides, the key regulators that control the ethanol accumulation from glucose even under aerobic conditions prior to be re-used on the stationary phase, have been provided from the genome sequence. Those are capital to reach an optimal astaxanthin production increasing the precursors availability by means of pathway engineering $[19,87]$. Also described was how $X$. dendrorhous is genetically fully equipped to cope with environmental oxidative stress that contributes to its genome shape [88].

The genome sequence also eased the phylogenetic analyses of this astaxanthin-producer basal agaricomycete with uncertain taxonomic placement, which presented Wallemia as the most basal agaricomycotinous lineage followed by Tremellomycetes. Besides, the taxonomic analysis defined a sister-group relationship between the core Tremellomycetes and the Cystofilobasidiales [19].

Two sampling points (18 and $72 \mathrm{~h}$ ) and two different carbon sources (glucose and succinate) were used by Baeza and co-workers [86] to obtain RNA after mechanical rupture by glass beads and Tri-Reagent (Ambion, Foster City, CA, USA) extraction (Table 2). The subsequent RNAseq analysis was the base to determine sequence lengths, expression levels, GC\% content, as well as the codon 
usage and codon context biases of the open reading frames (ORFs) [86]. A total of 1695 ORFs were the basis of the analysis in contrast with one previously described by Verdoes and van Ooyen [89] based on 10 ribosomal genes. Thus, a codon usage table of highly expressed ORFs of $X$. dendrorhous was properly defined, which is highly relevant for the heterologous expression of recombinant genes in the biotechnology industry [90].

Proteome analysis has been the most used omics methodology applied to X. dendrorhous, which goes from a reference map and mutant analysis to the comparison in the use of different carbon sources [91-94]. Besides, the sampling point and procedure help to discriminate those biomolecules directly involved in the process from those contaminants that include noise in the system. For example, this is the case of extracellular proteome (secretome) analysis, where proteins obtained by degradation (degradome) should be avoided [95]. To date, just the intra-cellular proteome has been analysed in X. dendrorhous. Those methodologies used for protein extraction, visualisation, and analysis are summarised in Table 2.

Firstly, Martínez-Moya and co-workers [93] developed a heterologous protein identification approach due to the poor genome characterisation at that time. Three time points were selected (lag, late exponential, and stationary growth phases) in minimal media (MM-glucose), where pigment accumulation is evident during the stationary phase. These authors identified two groups of up-regulated proteins: (i) carbohydrate and lipid metabolism proteins, which guarantee acetyl-CoA availability; and (ii) redox-specific proteins (e.g., monooxygenase or cytochrome P450). Both groups presented a scenario that supply the necessary redox potential for the late reactions of the astaxanthin synthesis. These results strongly suggested that astaxanthin production under aerobic conditions is a metabolic tool to scavenge ROS (reactive oxygen species) elements generated as metabolic byproducts in X. dendrorhous [93].

The same authors also studied by proteomics and metabolomics the influence of two different carbon sources (glucose (fermentable) or succinate (non-fermentable)) on the metabolism. Lipid and carbohydrate metabolism, carotenogenesis, as well as redox and stress responses proteins, were identified. These data confirmed the connection between the astaxanthin accumulation and oxidative stress in this yeast. Besides, the increase in acetyl-CoA availability when succinate is used as a carbon source was described, which could enhance the cellular respiration rate resulting in ROS elements that induces carotenogenesis [92].

In addition to the carbon source, the carbon to nitrogen ratio is crucial for microbial carotenoids production. This relation was analysed at fixed nitrogen concentrations by Pan and co-workers [94] in $X$. dendrorhous. Intriguingly, cell growth and astaxanthin accumulation were connected to the increasing of the carbon to nitrogen ratio, whereas the astaxanthin amount per cell was inverse. These metabolic adaptations were studied by two-dimensional electrophoresis analysis, where the up-regulation of redox- and stress-associated proteins, as well as carotenogenesis proteins were observed. In contrast, nine proteins involved in the astaxanthin synthesis were down-regulated and the de novo pigments synthesis was inhibited, which justify this peculiar unbalance between growth and cellular pigment accumulation [94].

As a result of nitrosoguanidine treatments, different coloured mutants (red, orange, pink, yellow, and white), which were analysed under the proteomics methodologies, were obtained by Barbachano-Torres and co-workers [91]. The red mutants were total carotenoids (mainly astaxanthin) overproducers, whereas orange and white ones accumulated phytoene as a result of phytoene dehydrogenase mutation. This analysis also demonstrated the close relation among the tricarboxylic acid cycle, stress response, and the carotenogenic process. 
Table 2. Summary of the biomolecules extraction protocols described for X. dendrorhous (P. rhodozyma).

\begin{tabular}{|c|c|c|c|c|}
\hline Media & Collection & Disruption & Analysis Method & Ref. \\
\hline \multicolumn{5}{|c|}{ DNA } \\
\hline \multirow[b]{2}{*}{$\begin{array}{l}\text { YPD medium. } \\
21^{\circ} \mathrm{C}, 5 \text { days }[96]\end{array}$} & \multirow[b]{2}{*}{$\begin{array}{l}\text { Culture: } 15 \mathrm{~mL} \\
\text { Suspended: } 0.5 \mathrm{~mL} \text { YPD }\end{array}$} & $\begin{array}{l}\text { Breaking system: } \\
300 \mu \mathrm{L} \text { of glass beads }(0.25-0.5 \mathrm{~mm} \text { diameter). } \\
\text { Swing mill (Retsch MM200) at a frequency of } 30 / \mathrm{s} \text {. }\end{array}$ & \multirow[b]{2}{*}{$\begin{array}{l}\text { Agarose gel and ethidium } \\
\text { bromide stain. } \\
\text { Fluorescence densitometry } \\
\text { measurement. }\end{array}$} & \multirow[b]{2}{*}{ [19] } \\
\hline & & $\begin{array}{l}\text { Sample cleaning: } \\
\text { Supernatant collected and purified by phenol/chloroform/isoamyl } \\
\text { alcohol extraction. } \\
\text { DNA precipitation overnight at }-20^{\circ} \mathrm{C} \text { by } 100 \% \text { ice-cold ethanol ( } 2.5 \text { volume) and } \\
1 / 10 \text { volume of } 3 \mathrm{M} \text { sodium acetate solution. } \\
70 \% \text { ice-cold ethanol. } \\
\text { Dry at room temperature. } \\
\text { DNA pellet resuspension in } 30 \mu \mathrm{L} \mathrm{H} \mathrm{H}_{2} \mathrm{O} \text {. } \\
\text { Store at } 4{ }^{\circ} \mathrm{C} \text {. }\end{array}$ & & \\
\hline \multirow{2}{*}{$\begin{array}{l}\mathrm{YM} \text { medium }(100 \mathrm{~mL}) . \\
22^{\circ} \mathrm{C} \text {, up to stationary phase }\end{array}$} & \multirow[b]{2}{*}{ Centrifugation } & $\begin{array}{l}\text { Breaking system: } \\
\text { DNA isolated from protoplasts: } \\
2 \times \text { wash } 50 \mathrm{mM} \text { EDTA pH } 7.5 \text {. } \\
\text { Novozyme } 234 \text { plus LET buffer ( } 500 \mathrm{mM} \text { EDTA, } 7.5 \% \text { 2-mercaptoethanol, } 10 \mathrm{mM} \\
\text { Tris pH } 7.5) .16 \mathrm{~h}, 37^{\circ} \mathrm{C} \text {. } \\
\text { NDS solution. } \\
(2 \mathrm{mg} / \mathrm{mL} \text { proteinase } \mathrm{K} \text { in } 500 \mathrm{mM} \text { EDTA, } 1 \% \text { lauryl sarcosine and } 10 \mathrm{mM} \\
\text { Tris-HCl, pH 7.5). } 24 \mathrm{~h}, 50^{\circ} \mathrm{C} \text {. }\end{array}$ & \multirow{2}{*}{$\begin{array}{l}\text { DNA quantitation: } 260 / 280 \\
\text { ratio (1.7-1.9) and } 260 / 230 \text { ratio } \\
\text { (>2) by using a V-630 UV-vis } \\
\text { Spectrophotometer. }\end{array}$} & \multirow[b]{2}{*}[85,86]{} \\
\hline & & $\begin{array}{l}\text { Sample cleaning: } \\
\text { Phenolic extraction ( } \mathrm{pH} 8.0) \text { : } \\
3 \times \text { wash saturated phenol. } \\
3 \times \text { phenol: chloroform: isoamyl alcohol (25:24:1). } \\
1 \times \text { chloroform: isoamyl alcohol (24:1). } \\
\text { DNA was precipitated with } 98 \% \text { ethanol and washed with } 70 \% \text { ethanol. } \\
\text { Dry DNA resuspended in Tris: EDTA }(10: 1 ; \mathrm{pH} 8.0) \text { plus } 40 \mu \mathrm{g} / \mathrm{mL} \text { of RNase A. } \\
37^{\circ} \mathrm{C}, 30 \text { min. } \\
\text { Repeat phenolic extraction }\end{array}$ & & \\
\hline \multirow[t]{2}{*}{ YM broth $(15 \mathrm{~mL})$ at $20^{\circ} \mathrm{C}, 72 \mathrm{~h}$} & \multirow[t]{2}{*}{ Centrifugation } & $\begin{array}{l}\text { Breaking system: } \\
\text { Modified phenol:chloroform:isoamyl alcohol method [97,98]: } \\
\text { Resuspend in } 500 \mu \mathrm{L} \text { lysis buffer ( } 10 \mathrm{mM} \text { Tris- } \mathrm{HCl} \mathrm{pH} 8.0,100 \mathrm{mM} \mathrm{NaCl}, 1 \mathrm{mM} \\
\text { EDTA (pH 8.0), } 2 \% \text { Triton X-100, } 1 \% \mathrm{SDS}) \text {. } \\
\text { Add an equal volume of phenol/chloroform }(1: 1 \mathrm{v} / \mathrm{v}) \text {. } \\
\text { Shake vigorously (Ika-Vibrax VXR shaker) at } 1800 \mathrm{rpm}, 20 \text { minutes, R/T. } \\
\text { Centrifuge at } 14,000 \mathrm{rpm}, 20 \mathrm{~min}, 4^{\circ} \mathrm{C} \text {. }\end{array}$ & \multirow[t]{2}{*}{$\mathrm{N} / \mathrm{A}$} & \multirow[t]{2}{*}{ [88] } \\
\hline & & $\begin{array}{l}\text { Sample cleaning: } \\
\text { Ethanol precipitation. }\end{array}$ & & \\
\hline
\end{tabular}


Table 2. Cont.

\begin{tabular}{|c|c|c|c|c|}
\hline Media & Collection & Disruption & Analysis Method & Ref. \\
\hline \multicolumn{5}{|c|}{ RNA } \\
\hline $\begin{array}{l}\text { YPD medium. } \\
21^{\circ} \mathrm{C}, 5 \text { days }[96]\end{array}$ & & $\begin{array}{l}\text { NucleoSpin }{ }^{\circledR} \text { RNA Plant kit (MACHEREY-NAGEL GmbH \& Co. KG) (Following } \\
\text { the manufacturer instructions). }\end{array}$ & $\begin{array}{c}\text { RNA quality by using } \\
\text { Nano-Photometer (IMPLEN) } \\
1.5 \% \text { agarose gel and ethidium } \\
\text { bromide stain }\end{array}$ & [19] \\
\hline \multirow[b]{2}{*}{$\begin{array}{l}\text { Vogel minimal medium (MMv) } \\
\text { supplemented with } 2 \% \text { glucose } \\
\text { or } 2 \% \text { succinate }\end{array}$} & \multirow[b]{2}{*}{$\begin{array}{l}\text { Early exponential phase } \\
(18 \mathrm{~h}) \\
\text { Initial stationary phase } \\
(72 \mathrm{~h})\end{array}$} & $\begin{array}{l}\text { Breaking system: } \\
\text { Mechanical rupture of cell pellets. } \\
0.5 \mathrm{~mm} \text { glass beads (BioSpec). } \\
\text { Vortexing for } 10 \mathrm{~min} . \\
\text { Add Tri-Reagent (Ambion). R/T } 10 \mathrm{~min} .\end{array}$ & \multirow[b]{2}{*}{$\begin{array}{l}\text { RNA quantitation: } 260 / 280 \\
\text { ratio (>1.9) by using a V- } 630 \\
\text { UV-vis Spectrophotometer }\end{array}$} & \multirow[b]{2}{*}{ [86] } \\
\hline & & $\begin{array}{l}\text { Sample cleaning: } \\
\text { Add } 200 \mu \mathrm{L} \text { of chloroform per } \mathrm{mL} \text { of Tri-Reagent. Mix. } \\
\text { Centrifuge: } 4000 \times g, 5 \mathrm{~min} . \\
\text { Recover supernatant. } \\
2 \times \text { acidic phenol: chloroform (1:1) extractions. } \\
\text { Precipitate: } 2 \text { volume of isopropanol. } 10 \mathrm{~min}, \mathrm{R} / \mathrm{T} \text {. } \\
1 \times \text { wash } 75 \% \text { ethanol. } \\
\text { Resuspend in RNase-free water. RNA samples at a } 260 / 280 \text { ratio }>1.9 \text {, measured } \\
\text { using a V-630 UV-vis Spectrophotometer, were used for } \\
\text { next-generation sequencing. }\end{array}$ & & \\
\hline \multirow{2}{*}{$\begin{array}{l}\text { Minimal medium plus } 2 \% \\
\text { glucose or succinate as carbon } \\
\text { sources [99] } \\
\text { Preculture: } 10 \mathrm{~mL} \\
\text { Culture: } 250 \mathrm{~mL} \text { in } 1 \text { - } \mathrm{L} \text { flask } \\
\text { inoculated with } 2.5 \mathrm{~mL} \text { of seed } \\
\text { culture. } \\
22^{\circ} \mathrm{C}, 120 \mathrm{rpm}\end{array}$} & $\begin{array}{l}\text { Centrifugation: } 5000 \times g, \\
10 \text { min, } 4^{\circ} \mathrm{C} \text {. Pellet } \\
\text { washed twice with }\end{array}$ & $\begin{array}{l}\text { Breaking system: } \\
\text { Lyophilise cells. } \\
\text { Add an equal volume }( \pm 500 \mu \mathrm{L}) \text { of glass beads }(500 \mu \mathrm{m}) \text {. } \\
\text { Add } 500 \mu \mathrm{L} \text { of lysis buffer }(100 \mathrm{mM} \text { sodium. bicarbonate, } \mathrm{pH} 8.8,0.5 \% \text { Triton } \times \\
100,1 \mathrm{mM} \text { phenylmethylsulfonyl fluoride (PMSF) and protease inhibitors). } \\
15 \mathrm{~min} \text { in on ice. } \\
\text { Shake at } 30 \mathrm{~s} \text { at } 4.5 \mathrm{~m} / \mathrm{s} \text { (RiboLyzer). } \\
\text { Chill on ice, } 1 \text { min between shaking steps. }\end{array}$ & \multirow{2}{*}{$\begin{array}{l}\text { Bidimensional gel (pI range: } \\
3-10 \mathrm{NL}, 17 \mathrm{~cm} \text { strips) } \\
\text { Coomassie brilliant blue } \\
\text { Trypsin digestion } \\
\text { MALDI-TOF-MS identification }\end{array}$} & \multirow[b]{2}{*}[92,93]{} \\
\hline & $\begin{array}{l}\text { ice-cold water. Centrifuge: } \\
5000 \times g, 10 \mathrm{~min}, 4^{\circ} \mathrm{C} \text {. } \\
\text { Freeze in liquid } \mathrm{N}_{2} \text {. Stored } \\
\text { at }-80^{\circ} \mathrm{C}\end{array}$ & $\begin{array}{l}\text { Sample cleaning: } \\
\text { Remove cell debris by centrifugation }\left(15,000 \mathrm{rpm}, 20 \mathrm{~min}, 4^{\circ} \mathrm{C} \text {. }\right. \\
10 \% v / v \text { DNase-RNase solution }(0.5 \mathrm{M} \text { Tris-HCl, } \mathrm{pH} 7.0,0.5 \mathrm{M} \mathrm{MgCl} 2,100 \mu \mathrm{g} / \mathrm{mL} \\
\text { RNAse and } 2 \mu \mathrm{L} \text { DNase). } 1 \mathrm{~h}, 4^{\circ} \mathrm{C} \text {. } \\
\text { Add water up to } 2.5 \mathrm{~mL} \text { plus } 200 \mu \mathrm{L} \text { of } 0.5 \mathrm{M} \text { Tris (pH } 6.8) \text { and } 20 \mu \mathrm{L} \text { of } 1 \mathrm{M} \\
\text { dithiothreitol (DTT). R/T. } 30 \mathrm{~min} \text {. } \\
600 \mu \mathrm{L} \text { of water-saturated phenol. R/T. } 30 \mathrm{~min} \text {. } \\
\text { Centrifuge: } 5000 \times g, 10 \mathrm{~min}, 4^{\circ} \mathrm{C} \\
\text { Add to supernatant } 20 \mu \mathrm{L} \text { of } 1 \mathrm{M} \text { DTT and } 30 \mu \mathrm{L} \text { of } 8 \mathrm{M} \text { ammonium acetate. R/T. } \\
30 \text { min. } \\
\text { Precipitate. } 2 \mathrm{~mL} \text { of cold }\left(-20^{\circ} \mathrm{C} \text { ) methanol. }\right.\end{array}$ & & \\
\hline
\end{tabular}


Table 2. Cont

\begin{tabular}{|c|c|c|c|c|}
\hline Media & Collection & Disruption & Analysis Method & Ref. \\
\hline & & $\begin{array}{l}\text { Centrifuge: } 13,000 \mathrm{rpm}, 4^{\circ} \mathrm{C}, 30 \mathrm{~min} . \\
2 \times \text { wash: } 70 \%(v / v) \text { cold ethanol at }-20^{\circ} \mathrm{C} \text {. } \\
\text { Resuspend pellet: } 200 \mu \mathrm{L} \text { of buffer }(8 \mathrm{M} \text { urea, } 2 \mathrm{M} \text { thiourea, } 2 \% \mathrm{CHAPS}, 0.01 \% \\
{[w / v] \text { bromophenol blue). }} \\
\text { Store at }-80^{\circ} \mathrm{C} \text {. }\end{array}$ & & \\
\hline \multirow{2}{*}{$\begin{array}{l}\text { YM medium 20-h old culture } \\
\text { (beginning of carotenoid } \\
\text { biosynthesis) } 20^{\circ} \mathrm{C} \text { and } \\
150 \mathrm{rpm} .\end{array}$} & \multirow{2}{*}{$\begin{array}{l}\text { Centrifugation: } \\
5000 \mathrm{rpm}, 10 \mathrm{~min} .\end{array}$} & $\begin{array}{l}\text { Breaking system: } \\
\text { Liquid nitrogen in a mortar } \\
\text { Resuspend fine powder in } 5 \mathrm{~mL} \text { of buffer ( } 50 \mathrm{mM} \text { Tris- } \mathrm{HCl} \mathrm{pH} 7.4,0.5 \mathrm{mM} \text { PMSF). } \\
\text { Add } 5 \mathrm{~mL} \text { of } 100 \mathrm{mM} \text { sodium carbonate. } \\
1 \mathrm{~h} \text { on ice. } \\
\text { Centrifuge: } 6000 \mathrm{rpm}, 20 \mathrm{~min}, 4^{\circ} \mathrm{C} \text {. } \\
\text { Supernatant precipitation: } 10 \% \text { final concentration of trichloroacetic acid (TCA). } \\
\text { Centrifuge: } 10,000 \mathrm{rpm} \text { for } 15 \mathrm{~min} \text {. }\end{array}$ & \multirow{2}{*}{$\begin{array}{l}\text { Bidimensional gel (pI range: } \\
\text { 3-10, } 11 \text { cm strips) } \\
\text { Colloidal Coomassie [100] }\end{array}$} & \multirow[b]{2}{*}{ [91] } \\
\hline & & $\begin{array}{l}\text { Sample cleaning: } \\
1 \times \text { acetone. } \\
1 \times 70 \% \text { ethanol. } \\
200 \mu \mathrm{L} \text { rehydration buffer }(7 \mathrm{M} \text { urea, } 2 \mathrm{M} \text { thiourea, } 1 \% \text { CHAPS, } 0.5 \% \text { Triton X-100, } \\
40 \mathrm{mM} \text { Tris-HCl, } 0.5 \% \text { ampholytes } 3-10 \text {, and } 0.1 \% \text { bromophenol blue). } \\
\text { Centrifuge: } 10,000 \mathrm{rpm}, 15 \mathrm{~min} \text {. } \\
\text { Desalt: Micro Bio Spin G-30 columns (Bio-Rad) and rehydration buffer (Bio-Rad, } \\
\text { Hercules, CA, USA). }\end{array}$ & & \\
\hline
\end{tabular}




\section{Conclusions and Future Prospects}

Commercial use of astaxanthin in aquiculture, as well as in human nutrition and health is well-defined and growing year after year. Nowadays, astaxanthin production is tackled by chemical synthesis, which allows a profitable cost/benefit ratio. However, its petrochemical origin presents regulatory concerns, which is shifting attention in favour of biological sources such as bacteria, yeasts, or algae. Unfortunately, some methodological (e.g., light induction, product extraction) or biotechnological difficulties (e.g., low production) are the current key concerns of a more eco-friendly production process. The practical advances (culture conditions, transformation processes, high throughput screening systems, genetic and metabolic know-how, scale up processes) supported by omics technologies are boosting the carotenoids production by natural procedures. Thus, X. dendrorhous, which has been approved by the FDA for the commercial production of astaxanthin, is a good candidate to allow the natural production of astaxanthin with a proper isomerism and chemical structure. There is good knowledge and a methodological basis, but the natural production of astaxanthin has plenty of room for improvement.

Acknowledgments: We thank Josefina Merino, Bernabé Martín, Andrea Casenave and Hanna del Río for their excellent technical assistance and the doctorate and degree students of the group Laura García Calvo, Ana García-Guerra, Ana Ibáñez and Esmeralda Sastre.

Conflicts of Interest: The authors declare no conflict of interest.

\section{References}

1. Lichtenthaler, H.K.; Buschmann, C. Chlorophylls and Carotenoids: Measurement and Characterization by UV-VIS Spectroscopy. In Current Protocols Food Analytical Chemistry; John Wiley \& Sons, Inc.: Franklin, NJ, USA, 2001. [CrossRef]

2. Sandmann, G.; Misawa, N. Fungal Carotenoids. In Industrial Application; Osiewacz, H.D., Ed.; Springer: Berlin/Heidelberg, Germany, 2002; pp. 247-262. [CrossRef]

3. Sieiro, C.; Poza, M.; de Miguel, T.; Villa, T.G. Genetic basis of microbial carotenogenesis. Int. Microbiol. 2003, 6, 11-16. [PubMed]

4. Fraser, P.D.; Bramley, P.M. The biosynthesis and nutritional uses of carotenoids. Prog. Lipid Res. 2004, 43, 228-265. [CrossRef] [PubMed]

5. Britton, G.; Liaaen-Jensen, S.; Pfander, H. Carotenoids; Birkhäuser Basel: Basel, Switzerland, 2004. [CrossRef]

6. Bhosale, P.; Bernstein, P.S. Microbial xanthophylls. Appl. Microbiol. Biotechnol. 2005, 68, 445-455. [CrossRef] [PubMed]

7. Young, A.J. The photoprotective role of carotenoids in higher plants. Physiol. Plant. 1991, 83, 702-708. [CrossRef]

8. Blomhoff, R.; Blomhoff, H.K. Overview of retinoid metabolism and function. J. Neurobiol. 2006, 66, 606-630. [CrossRef] [PubMed]

9. Walter, M.H.; Strack, D. Carotenoids and their cleavage products: Biosynthesis and functions. Nat. Prod. Rep. 2011, 28, 663-692. [CrossRef] [PubMed]

10. Fiedor, J.; Burda, K. Potential role of carotenoids as antioxidants in human health and disease. Nutrients 2014, 6, 466-488. [CrossRef] [PubMed]

11. Biesalski, H.K.; Chichili, G.R.; Frank, J.; von Lintig, J.; Nohr, D. Conversion of $\beta$-carotene to retinal pigment. Vitam. Horm. 2007, 75, 117-130. [PubMed]

12. Feltl, L.; Pacakova, V.; Stulik, K.; Volka, K. Reliability of Carotenoid Analyses: A Review. Curr. Anal. Chem. 2005, 1, 93-102. [CrossRef]

13. März, U. The Global Market for Carotenoids. Available online: https://www.bccresearch.com/marketResearch/food-and-Beverage/carotenoids-Global-Market-Report-fod025e.html (accessed on 13 June 2017).

14. Panis, G.; Carreon, J.R. Commercial astaxanthin production derived by green alga Haematococcus pluvialis: A microalgae process model and a techno-economic assessment all through production line. Algal Res. 2016, 18, 175-190. [CrossRef] 
15. Schweiggert, R.M.; Carle, R. Carotenoid Production by Bacteria, Microalgae, and Fungi. In Carotenoids Nutrition Analysis Technology; Kaczor, A., Baranska, M., Eds.; John Wiley \& Sons, Ltd: Chichester, UK, 2016; pp. 217-240.

16. Phaff, H.; Miller, M.; Yoneyama, M.; Soneda, M. A comparative study of the yeast florae associated with trees on the Japanese Islands and on the west coast of North America. In Proceedings of the 4th Internatoinal Fermentation Symposium: Fermentation Technology Today, Kyoto, Japan, 19-25 March 1972; pp. 759-774.

17. Andrewes, A.G.; Starr, M.P. (3R, $3^{\prime}$ R)-Astaxanthin from the yeast Phaffia rhodozyma. Phytochemistry 1976, 15, 1009-1011. [CrossRef]

18. Sandmann, G. Carotenoids of Biotechnological Importance. In Biotechnology of Isoprenoids; Schrader, J., Bohlmann, J., Eds.; Springer International Publishing: Cham, Switzerland, 2014; pp. 449-467. [CrossRef]

19. Sharma, R.; Gassel, S.; Steiger, S.; Xia, X.; Bauer, R.; Sandmann, G.; Thines, M. The genome of the basal agaricomycete Xanthophyllomyces dendrorhous provides insights into the organization of its acetyl-CoA derived pathways and the evolution of Agaricomycotina. BMC Genom. 2015, 16, 233. [CrossRef] [PubMed]

20. Visser, H.; Sandmann, G.; Verdoes, J.C. Xanthophylls in Fungi. Metabolic Engineering of the Astaxanthin Biosynthetic Pathway in Xanthophyllomyces dendrorhous. In Microbial Processes Products; Barredo, J.-L., Ed.; Humana Press: Totowa, NJ, USA, 2005; pp. 257-272.

21. Rodríguez-Sáiz, M.; Godio, R.P.; Alvarez, V.; de la Fuente, J.L.; Martín, J.F.; Barredo, J.L. The NADP-dependent glutamate dehydrogenase gene from the astaxanthin producer Xanthophyllomyces dendrorhous: Use of Its promoter for controlled gene expression. Mol. Biotechnol. 2009, 41, 165-172. [CrossRef] [PubMed]

22. Gassel, S.; Breitenbach, J.; Sandmann, G. Genetic engineering of the complete carotenoid pathway towards enhanced astaxanthin formation in Xanthophyllomyces dendrorhous starting from a high-yield mutant. Appl. Microbiol. Biotechnol. 2014, 98, 345-350. [CrossRef] [PubMed]

23. Hara, K.Y.; Morita, T.; Mochizuki, M.; Yamamoto, K.; Ogino, C.; Araki, M.; Kondo, A. Development of a multi-gene expression system in Xanthophyllomyces dendrorhous. Microb. Cell Fact. 2014, 13, 175. [CrossRef] [PubMed]

24. Yamane, Y.; Higashida, K.; Nakashimada, Y.; Kakizono, T.; Nishio, N. Influence of Oxygen and Glucose on Primary Metabolism and Astaxanthin Production by Phaffia rhodozyma in Batch and Fed-Batch Cultures: Kinetic and Stoichiometric Analysis. Appl. Environ. Microbiol. 1997, 63, 4471-4478. [PubMed]

25. Alvarez, V.; Rodríguez-Sáiz, M.; de la Fuente, J.L.; Gudiña, E.J.; Godio, R.P.; Martín, J.F.; Barredo, J.L. The crtS gene of Xanthophyllomyces dendrorhous encodes a novel cytochrome-P450 hydroxylase involved in the conversion of $\beta$-carotene into astaxanthin and other xanthophylls. Fungal Genet. Biol. 2006, 43, 261-272. [CrossRef] [PubMed]

26. Ojima, K.; Breitenbach, J.; Visser, H.; Setoguchi, Y.; Tabata, K.; Hoshino, T.; van den Berg, J.; Sandmann, G. Cloning of the astaxanthin synthase gene from Xanthophyllomyces dendrorhous (Phaffia rhodozyma) and its assignment as a $\beta$-carotene 3-hydroxylase/4-ketolase. Mol. Genet. Genom. 2006, 275, 148-158. [CrossRef] [PubMed]

27. Green, A.S.; Fascetti, A.J. Meeting the Vitamin A Requirement: The Efficacy and Importance of $\beta$-Carotene in Animal Species. Sci. World J. 2016, 2016, 7393620. [CrossRef] [PubMed]

28. Chichili, G.R.; Nohr, D.; Schäffer, M.; von Lintig, J.; Biesalski, H.K. $\beta$-Carotene conversion into vitamin A in human retinal pigment epithelial cells. Investig. Ophthalmol. Vis. Sci. 2005, 46, 3562-3569. [CrossRef] [PubMed]

29. Zhang, W.; Zhang, K.Y.; Ding, X.M.; Bai, S.P.; Hernandez, J.M.; Yao, B.; Zhu, Q. Influence of canthaxanthin on broiler breeder reproduction, chick quality, and performance. Poult. Sci. 2011, 90, 1516-1522. [CrossRef] [PubMed]

30. Bone, R.A.; Landrum, J.T.; Friedes, L.M.; Gomez, C.M.; Kilburn, M.D.; Menendez, E.; Vidal, I.; Wang, W. Distribution of lutein and zeaxanthin stereoisomers in the human retina. Exp. Eye Res. 1997, 64, 211-218. [CrossRef] [PubMed]

31. Landrum, J.T.; Bone, R.A. Lutein, zeaxanthin, and the macular pigment. Arch. Biochem. Biophys. 2001, 385, 28-40. [CrossRef] [PubMed]

32. Lima, V.C.; Rosen, R.B.; Farah, M. Macular pigment in retinal health and disease. Int. J. Retina Vitr. 2016, 2, 19. [CrossRef] [PubMed] 
33. Research and Markets, Global Astaxanthin Market-Sources, Technologies and Application. Available online: http:/ / www.researchandmarkets.com/reports/3129287/global-astaxanthin-market-sources-technologies (accessed on 21 May 2017).

34. Schmidt, I.; Schewe, H.; Gassel, S.; Jin, C.; Buckingham, J.; Hümbelin, M.; Sandmann, G.; Schrader, J. Biotechnological production of astaxanthin with Phaffia rhodozyma/Xanthophyllomyces dendrorhous. Appl. Microbiol. Biotechnol. 2011, 89, 555-571. [CrossRef] [PubMed]

35. Breithaupt, D.R. Xanthophylls in Poultry Feeding. In Carotenoids; Britton, G., Liaaen-Jensen, S., Pfander, H., Eds.; Birkhäuser Basel: Basel, Switzerland, 2008; Volume 4, pp. 255-264.

36. Higuera-Ciapara, I.; Félix-Valenzuela, L.; Goycoolea, F.M. Astaxanthin: A review of its chemistry and applications. Crit. Rev. Food Sci. Nutr. 2006, 46, 185-196. [CrossRef] [PubMed]

37. Wang, X.; Willén, R.; Wadström, T. Astaxanthin-rich algal meal and vitamin C inhibit Helicobacter pylori infection in BALB/cA mice. Antimicrob. Agents Chemother. 2000, 44, 2452-2457. [CrossRef] [PubMed]

38. Park, J.S.; Chyun, J.H.; Kim, Y.K.; Line, L.L.; Chew, B.P. Astaxanthin decreased oxidative stress and inflammation and enhanced immune response in humans. Nutr. Metab. 2010, 7, 18. [CrossRef] [PubMed]

39. Yasui, Y.; Hosokawa, M.; Mikami, N.; Miyashita, K.; Tanaka, T. Dietary astaxanthin inhibits colitis and colitis-associated colon carcinogenesis in mice via modulation of the inflammatory cytokines. Chem. Biol. Interact. 2011, 193, 79-87. [CrossRef] [PubMed]

40. Fassett, R.G.; Coombes, J.S. Astaxanthin, oxidative stress, inflammation and cardiovascular disease. Future Cardiol. 2009, 5, 333-342. [CrossRef] [PubMed]

41. Li, J.; Zhu, D.; Niu, J.; Shen, S.; Wang, G. An economic assessment of astaxanthin production by large scale cultivation of Haematococcus pluvialis. Biotechnol. Adv. 2011, 29, 568-574. [CrossRef] [PubMed]

42. An, G.H.; Cho, M.H.; Johnson, E.A. Monocyclic carotenoid biosynthetic pathway in the yeast Phaffia rhodozyma (Xanthophyllomyces dendrorhous). J. Biosci. Bioeng. 1999, 88, 189-193. [CrossRef]

43. Rodríguez-Sáiz, M.; de la Fuente, J.L.; Barredo, J.L. Xanthophyllomyces dendrorhous for the industrial production of astaxanthin. Appl. Microbiol. Biotechnol. 2010, 88, 645-658. [CrossRef] [PubMed]

44. Priya, R.; Hridya, H.; Soundarya, C.; Somasundari, G.; Doss, C.G.P.; Sneha, P.; Rajasekaran, C.; Christopher, G.; Siva, R. Astaxanthin biosynthetic pathway: Molecular phylogenies and evolutionary behaviour of Crt genes in eubacteria. Plant Gene 2016, 8, 32-41. [CrossRef]

45. Andrewes, A.G.; Phaff, H.J.; Starr, M.P. Carotenoids of Phaffia rhodozyma, a red-pigmented fermenting yeast. Phytochemistry 1976, 15, 1003-1007. [CrossRef]

46. Sanpietro, L.M.D.; Kula, M.R. Studies of astaxanthin biosynthesis in Xanthophyllomyces dendrorhous (Phaffia rhodozyma). Effect of inhibitors and low temperature. Yeast 1998, 14, 1007-1016. [CrossRef]

47. Verdoes, J.C.; Sandmann, G.; Visser, H.; Diaz, M.; van Mossel, M.; van Ooyen, A.J.J. Metabolic engineering of the carotenoid biosynthetic pathway in the yeast Xanthophyllomyces dendrorhous (Phaffia rhodozyma). Appl. Environ. Microbiol. 2003, 69, 3728-3738. [CrossRef] [PubMed]

48. Visser, H.; van Ooyen, A.J.J.; Verdoes, J.C. Metabolic engineering of the astaxanthin-biosynthetic pathway of Xanthophyllomyces dendrorhous. FEMS Yeast Res. 2003, 4, 221-231. [CrossRef]

49. Liang, P.-H.; Ko, T.-P.; Wang, A.H.-J. Structure, mechanism and function of prenyltransferases. Eur. J. Biochem. 2002, 269, 3339-3354. [CrossRef] [PubMed]

50. Lee, P.C.; Schmidt-Dannert, C. Metabolic engineering towards biotechnological production of carotenoids in microorganisms. Appl. Microbiol. Biotechnol. 2002, 60, 1-11. [PubMed]

51. Misawa, N. Pathway engineering for functional isoprenoids. Curr. Opin. Biotechnol. 2011, 22, $627-633$. [CrossRef] [PubMed]

52. Kajiwara, S.; Fraser, P.D.; Kondo, K.; Misawa, N. Expression of an exogenous isopentenyl diphosphate isomerase gene enhances isoprenoid biosynthesis in Escherichia coli. Biochem. J. 1997, 324, 421-426. [CrossRef] [PubMed]

53. Britton, G. Carotenoid Biosynthesis-An Overview. In Carotenoids Chemistry Biology; Krinsky, N.I., Mathews-Roth, M.M., Taylor, R.F., Eds.; Springer: Boston, MA, USA, 1989; pp. 167-184.

54. Niklitschek, M.; Alcaíno, J.; Barahona, S.; Sepúlveda, D.; Lozano, C.; Carmona, M.; Marcoleta, A.; Martínez, C.; Lodato, P.; Baeza, M.; et al. Genomic organization of the structural genes controlling the astaxanthin biosynthesis pathway of Xanthophyllomyces dendrorhous. Biol. Res. 2008, 41, 93-108. [CrossRef] [PubMed] 
55. Verdoes, J.C.; Krubasik, K.P.; Sandmann, G.; van Ooyen, A.J. Isolation and functional characterisation of a novel type of carotenoid biosynthetic gene from Xanthophyllomyces dendrorhous. Mol. Gen. Genet. 1999, 262, 453-461. [CrossRef] [PubMed]

56. Ajikumar, P.K.; Tyo, K.; Carlsen, S.; Mucha, O.; Phon, T.H.; Stephanopoulos, G. Terpenoids: Opportunities for biosynthesis of natural product drugs using engineered microorganisms. Mol. Pharm. 2008, 5, 167-190. [CrossRef] [PubMed]

57. Verdoes, J.C.; Misawa, N.; van Ooyen, A.J. Cloning and characterization of the astaxanthin biosynthetic gene encoding phytoene desaturase of Xanthophyllomyces dendrorhous. Biotechnol. Bioeng. 1999, 63, 750-755. [CrossRef]

58. Krubasik, P.; Sandmann, G. A carotenogenic gene cluster from Brevibacterium linens with novel lycopene cyclase genes involved in the synthesis of aromatic carotenoids. Mol. Gen. Genet. 2000, 263, 423-432. [CrossRef] [PubMed]

59. Alcaíno, J.; Barahona, S.; Carmona, M.; Lozano, C.; Marcoleta, A.; Niklitschek, M.; Sepúlveda, D.; Baeza, M.; Cifuentes, V. Cloning of the cytochrome p450 reductase ( $c r t R)$ gene and its involvement in the astaxanthin biosynthesis of Xanthophyllomyces dendrorhous. BMC Microbiol. 2008, 8, 169. [CrossRef] [PubMed]

60. Ukibe, K.; Hashida, K.; Yoshida, N.; Takagi, H. Metabolic engineering of Saccharomyces cerevisiae for astaxanthin production and oxidative stress tolerance. Appl. Environ. Microbiol. 2009, 75, 7205-7211. [CrossRef] [PubMed]

61. Calo, P.; González, T. The yeast Phaffia rhodozyma as an industrial source of astaxanthin. Microbiologia 1995, 11, 386-388. [PubMed]

62. Alcaino, J.; Baeza, M.; Cifuentes, V. Astaxanthin and Related Xanthophylls. In Biosynthesis Molecular Genetics of Fungal Secondary Metabolites; Martín, J.-F., Garcia-Estrada, C., Zeilinger, S., Eds.; Springer: New York, NY, USA, 2014; pp. 187-207.

63. Ukibe, K.; Katsuragi, T.; Tani, Y.; Takagi, H. Efficient screening for astaxanthin-overproducing mutants of the yeast Xanthophyllomyces dendrorhous by flow cytometry. FEMS Microbiol. Lett. 2008, 286, 241-248. [CrossRef] [PubMed]

64. An, G.H.; Schuman, D.B.; Johnson, E.A. Isolation of Phaffia rhodozyma Mutants with Increased Astaxanthin Content. Appl. Environ. Microbiol. 1989, 55, 116-124. [PubMed]

65. Retamales, P.; León, R.; Martínez, C.; Hermosilla, G.; Pincheira, G.; Cifuentes, V. Complementation analysis with new genetic markers in Phaffia rhodozyma. Antonie Van Leeuwenhoek 1998, 73, 229-236. [CrossRef] [PubMed]

66. De la Fuente Moreno, J.L.; Peiro, E.; Díez García, B.; Marcos Rodríguez, A.T.; Schleissner, C.; Rodríguez Saiz, M.; Rodríguez-Otero, C.; Cabri, W.; Barredo, J.L. Method of Producing Astaxanthin by Fermenting Selected Strains of Xanthophyllomyces dendrorhous. Patent EP1479777A1, 3 February 2003.

67. Liu, Z.Q.; Zhang, J.F.; Zheng, Y.G.; Shen, Y.C. Improvement of astaxanthin production by a newly isolated Phaffia rhodozyma mutant with low-energy ion beam implantation. J. Appl. Microbiol. 2008, 104, 861-872. [CrossRef] [PubMed]

68. Ni, H.; Hong, Q.; Xiao, A.; Li, L.; Cai, H.; Su, W. Characterization and evaluation of an astaxanthin over-producing Phaffia rhodozyma. Sheng Wu Gong Cheng Xue Bao (Chinese J. Biotechnol.) 2011, 27, 1065-1075.

69. Johnson, E.A. Phaffia rhodozyma: Colorful odyssey. Int. Microbiol. 2003, 6, 169-174. [CrossRef] [PubMed]

70. Chumpolkulwong, N.; Kakizono, T.; Nagai, S.; Nishio, N. Increased astaxanthin production by Phaffia rhodozyma mutants isolated as resistant to diphenylamine. J. Ferment. Bioeng. 1997, 83, 429-434. [CrossRef]

71. Schroeder, W.A.; Calo, P.; DeClercq, M.L.; Johnson, E.A. Selection for carotenogenesis in the yeast Phaffia rhodozyma by dark-generated singlet oxygen. Microbiology 1996, 142, 2923-2929. [CrossRef]

72. An, G.H.; Johnson, E.A. Influence of light on growth and pigmentation of the yeast Phaffia rhodozyma. Antonie Van Leeuwenhoek 1990, 57, 191-203. [CrossRef] [PubMed]

73. Pérez-García, F.; Vasco-Cárdenas, M.F.; Barreiro, C. Biotypes analysis of Corynebacterium glutamicum growing in dicarboxylic acids demonstrates the existence of industrially-relevant intra-species variations. J. Proteom. 2016, 146, 172-183. [CrossRef] [PubMed]

74. Breitenbach, J.; Visser, H.; Verdoes, J.C.; van Ooyen, A.J.J.; Sandmann, G. Engineering of geranylgeranyl pyrophosphate synthase levels and physiological conditions for enhanced carotenoid and astaxanthin synthesis in Xanthophyllomyces dendrorhous. Biotechnol. Lett. 2011, 33, 755-761. [CrossRef] [PubMed] 
75. Gassel, S.; Schewe, H.; Schmidt, I.; Schrader, J.; Sandmann, G. Multiple improvement of astaxanthin biosynthesis in Xanthophyllomyces dendrorhous by a combination of conventional mutagenesis and metabolic pathway engineering. Biotechnol. Lett. 2013, 35, 565-569. [CrossRef] [PubMed]

76. Wery, J.; Verdoes, J.C.; van Ooyen, A.J.J. Efficient Transformation of the Astaxanthin-Producing Yeast Phaffia rhodozyma. Biotechnol. Tech. 1998, 12, 399-405. [CrossRef]

77. Yamamoto, K.; Hara, K.Y.; Morita, T.; Nishimura, A.; Sasaki, D.; Ishii, J.; Ogino, C.; Kizaki, N.; Kondo, A. Enhancement of astaxanthin production in Xanthophyllomyces dendrorhous by efficient method for the complete deletion of genes. Microb. Cell Fact. 2016, 15, 155. [CrossRef] [PubMed]

78. Hara, K.Y.; Morita, T.; Endo, Y.; Mochizuki, M.; Araki, M.; Kondo, A. Evaluation and screening of efficient promoters to improve astaxanthin production in Xanthophyllomyces dendrorhous. Appl. Microbiol. Biotechnol. 2014, 98, 6787-6793. [CrossRef] [PubMed]

79. Martín, J.F.; Gudiña, E.; Barredo, J.L. Conversion of $\beta$-carotene into astaxanthin: Two separate enzymes or a bifunctional hydroxylase-ketolase protein? Microb. Cell Fact. 2008, 7, 3. [CrossRef] [PubMed]

80. Lodato, P.; Alcaíno, J.; Barahona, S.; Niklitschek, M.; Carmona, M.; Wozniak, A.; Baeza, M.; Jiménez, A.; Cifuentes, V. Expression of the carotenoid biosynthesis genes in Xanthophyllomyces dendrorhous. Biol. Res. 2007, 40, 73-84. [CrossRef] [PubMed]

81. Chi, S.; He, Y.; Ren, J.; Su, Q.; Liu, X.; Chen, Z.; Wang, M.; Li, Y.; Li, J. Overexpression of a bifunctional enzyme, CrtS, enhances astaxanthin synthesis through two pathways in Phaffia rhodozyma. Microb. Cell Fact. 2015, 14, 90. [CrossRef] [PubMed]

82. Ledetzky, N.; Osawa, A.; Iki, K.; Pollmann, H.; Gassel, S.; Breitenbach, J.; Shindo, K.; Sandmann, G. Multiple transformation with the $c r t Y B$ gene of the limiting enzyme increased carotenoid synthesis and generated novel derivatives in Xanthophyllomyces dendrorhous. Arch. Biochem. Biophys. 2014, 545, 141-147. [CrossRef] [PubMed]

83. Zheng, Y.G.; Hu, Z.C.; Wang, Z.; Shen, Y.C. Large-Scale Production of Astaxanthin by Xanthophyllomyces dendrorhous. Food Bioprod. Process. 2006, 84, 164-166. [CrossRef]

84. De la Fuente, J.L.; Rodríguez-Sáiz, M.; Schleissner, C.; Díez, B.; Peiro, E.; Barredo, J.L. High-titer production of astaxanthin by the semi-industrial fermentation of Xanthophyllomyces dendrorhous. J. Biotechnol. 2010, 148, 144-146. [CrossRef] [PubMed]

85. Cifuentes, V.; Hermosilla, G.; Martínez, C.; León, R.; Pincheira, G.; Jiménez, A. Genetics and electrophoretic karyotyping of wild-type and astaxanthin mutant strains of Phaffia rhodozyma. Antonie Van Leeuwenhoek 1997, 72, 111-117. [CrossRef] [PubMed]

86. Baeza, M.; Alcaíno, J.; Barahona, S.; Sepúlveda, D.; Cifuentes, V. Codon usage and codon context bias in Xanthophyllomyces dendrorhous. BMC Genom. 2015, 16, 1-12. [CrossRef] [PubMed]

87. Wozniak, A.; Lozano, C.; Barahona, S.; Niklitschek, M.; Marcoleta, A.; Alcaíno, J.; Sepulveda, D.; Baeza, M.; Cifuentes, V. Differential carotenoid production and gene expression in Xanthophyllomyces dendrorhous grown in a nonfermentable carbon source. FEMS Yeast Res. 2011, 11, 252-262. [CrossRef] [PubMed]

88. Bellora, N.; Moliné, M.; David-Palma, M.; Coelho, M.A.; Hittinger, C.T.; Sampaio, J.P.; Gonçalves, P.; Libkind, D. Comparative genomics provides new insights into the diversity, physiology, and sexuality of the only industrially exploited tremellomycete: Phaffia rhodozyma. BMC Genom. 2016, 17, 901. [CrossRef] [PubMed]

89. Verdoes, J.C.; van Ooyen, A.J.J. Codon usage in Xanthophyllomyces dendrorhous (formerly Phaffia rhodozyma). Biotechnol. Lett. 2000, 22, 9-13. [CrossRef]

90. Elena, C.; Ravasi, P.; Castelli, M.E.; Peirú, S.; Menzella, H.G. Expression of codon optimized genes in microbial systems: Current industrial applications and perspectives. Front. Microbiol. 2014, 5, 21. [CrossRef] [PubMed]

91. Barbachano-Torres, A.; Castelblanco-Matiz, L.M.; Ramos-Valdivia, A.C.; Cerda-García-Rojas, C.M.; Salgado, L.M.; Flores-Ortiz, C.M.; Ponce-Noyola, T. Analysis of proteomic changes in colored mutants of Xanthophyllomyces dendrorhous (Phaffia rhodozyma). Arch. Microbiol. 2014, 196, 411-421. [CrossRef] [PubMed]

92. Martinez-Moya, P.; Niehaus, K.; Alcaíno, J.; Baeza, M.; Cifuentes, V. Proteomic and metabolomic analysis of the carotenogenic yeast Xanthophyllomyces dendrorhous using different carbon sources. BMC Genom. 2015, 16, 289. [CrossRef] [PubMed] 
93. Martinez-Moya, P.; Watt, S.A.; Niehaus, K.; Alcaíno, J.; Baeza, M.; Cifuentes, V. Proteomic analysis of the carotenogenic yeast Xanthophyllomyces dendrorhous. BMC Microbiol. 2011, 11, 131. [CrossRef] [PubMed]

94. Pan, X.; Wang, B.; Gerken, H.G.; Lu, Y.; Ling, X. Proteomic analysis of astaxanthin biosynthesis in Xanthophyllomyces dendrorhous in response to low carbon levels. Bioprocess Biosyst. Eng. 2017. [CrossRef] [PubMed]

95. Barreiro, C.; Martín, J.F.; García-Estrada, C. Proteomics Shows New Faces for the Old Penicillin Producer Penicillium chrysogenum. J. Biomed. Biotechnol. 2012, 2012, 1-15. [CrossRef] [PubMed]

96. Ausubel, F.; Brent, R.; Kingston, R.; Moore, D.; Seidman, J.; Smith, J.; Struhl, K. YPD media. In Current Protocols Molecular Biology Cold Spring Harbor Protocols; Cold Spring Harbor Laboratory Press: Brooklyn, NY, USA, 1994. [CrossRef]

97. Gonçalves, P.; Valério, E.; Correia, C.; de Almeida, J.M.G.C.F.; Sampaio, J.P. Evidence for divergent evolution of growth temperature preference in sympatric Saccharomyces species. PLoS ONE 2011, 6, e20739. [CrossRef] [PubMed]

98. Soni, R.; Murray, J.A. A rapid and inexpensive method for isolation of shuttle vector DNA from yeast for the transformation of E. coli. Nucleic Acids Res. 1992, 20, 5852. [CrossRef] [PubMed]

99. Retamales, P.; Hermosilla, G.; León, R.; Martínez, C.; Jiménez, A.; Cifuentes, V. Development of the sexual reproductive cycle of Xanthophyllomyces dendrorhous. J. Microbiol. Methods 2002, 48, 87-93. [CrossRef]

100. Candiano, G.; Bruschi, M.; Musante, L.; Santucci, L.; Ghiggeri, G.M.; Carnemolla, B.; Orecchia, P.; Zardi, L.; Righetti, P.G. Blue silver: A very sensitive colloidal Coomassie G-250 staining for proteome analysis. Electrophoresis 2004, 25, 1327-1333. [CrossRef] [PubMed]

(C) 2017 by the authors. Licensee MDPI, Basel, Switzerland. This article is an open access article distributed under the terms and conditions of the Creative Commons Attribution (CC BY) license (http:/ / creativecommons.org/licenses/by/4.0/). 